\title{
So many visitors and so few pollinators: variation in insect frequency and effectiveness governs the reproductive success of an endemic milkwort
}

\author{
Sílvia Castro • João Loureiro • Victoria Ferrero • \\ Paulo Silveira $\cdot$ Luis Navarro
}

Received: 21 May 2013/Accepted: 31 July 2013/Published online: 9 August 2013

(C) Springer Science+Business Media Dordrecht 2013

\begin{abstract}
Plant-pollinator interactions are one of the most important and variable mutualisms having major implications for plant fitness. The present study evaluates the interactions between an endemic milkwort, Polygala vayredae, and its floral visitors by studying the temporal variability, foraging behaviour and effectiveness of floral visitors in three populations during three consecutive years. The flowers were visited by a diverse array of insects, totalling 24 different species. However, only four species were effective pollinators, depositing pollen on stigmas after one visit, while the remaining species behaved as nectar robbers, secondary nectar robbers or nectar thieves and were completely ineffective for pollination. Among the effective pollinators, two groups with distinct foraging behaviours were observed: the nectar
\end{abstract}

Present Address:

S. Castro $(\varangle) \cdot$ J. Loureiro $\cdot$ V. Ferrero

Department of Life Sciences, Centre for Functional Ecology (CFE), University of Coimbra, PO Box 3046, 3001-401 Coimbra, Portugal

e-mail: scastro@bot.uc.pt

V. Ferrero $\cdot$ L. Navarro

Department of Plant Biology and Soil Sciences, Faculty of Biology, University of Vigo, As Lagoas-Marcosende, 36200 Vigo, Spain

\section{P. Silveira}

Department of Biology, CESAM, University of Aveiro, Campus Universitário de Santiago, 3810-193 Aveiro, Portugal collecting long-tongued bees Bombus pascuorum and Anthophora sp. and the pollen collectors Eucera longicornis and Halictus sp. No significant differences were observed among pollinators in their efficiency in pollen deposition on stigmas, but significant differences were observed in the foraging behaviour between nectarivorous and pollen collectors. Variation in the abundance and assemblage of floral visitors was observed at the temporal scale and among populations, with the effective pollinators being generally scarce. Consequently, the reproductive outcome in this species was low and significantly variable among populations and years. The results highlight the importance of studying floral visitor effectiveness when determining pollinator assemblages.

Keywords Legitimate visitors · Nectar robbing $\cdot$ Plant-animal interactions $\cdot$ Pollination effectiveness $\cdot$ Polygala vayredae $\cdot$ Polygalaceae

\section{Introduction}

The majority of the flowering plants rely on animal vectors to transport their pollen to the stigmas of conspecific flowers. Consequently, plant-pollinator interactions are one of the most important and variable mutualism in nature and an important ecosystem service. While some flower-visitor interactions are 
mutualistic many do not provide any 'reward' or benefit for the partner. For example, flowers may promise food or sex but provide none (pollination by deceit, e.g., Jersáková et al. 2006) or visitors may extract nectar from the flowers without pollinating them (nectar robbers, e.g., Irwin et al. 2001; Castro et al. 2008a).

The diversity and behaviour of floral visitors has major consequences for plant reproductive outcomes (e.g., Pellmyr and Thompson 1996; Traveset and Sáez 1997; Moeller 2006). Floral visitors show variable foraging strategies, visitation rates, pollen removal and deposition abilities, and/or variable handling times (e.g., Schemske and Horvitz 1984; Sahly and Conner 2007; Ferrero et al. 2011). These features will affect the quantitative and qualitative components of pollination, ultimately leading to different levels of effectiveness and to specific contributions to plant fitness (through both seed production and seed quality; e.g., Schemske and Horvitz 1984; Artz et al. 2010). In addition, pollen limitation has been suggested to frequently compromise seed production in plant populations due to the scarcity of pollinators or the low quantity and/or quality of the delivered pollen (e.g., Navarro 1998; Aizen and Harder 2007; Castro et al. 2008b).

Because floral visitors frequently vary in abundance and efficiency between years and sites (e.g., Traveset and Sáez 1997; Fenster and Dudash 2001; Moeller 2006), studies of temporal and spatial variability in visitor assemblages and their effects on plant reproductive outcome are essential to understand plant population dynamics. This is particularly important in threatened or narrowly distributed species, as well as to understand the patterns of pollinator-mediated selection (Schemske and Horvitz 1984; Herrera 1988; Schemske et al. 1994; Guitián et al. 1996; Ashman et al. 2004). While spatial variation in plantpollinator interactions has been shown to promote divergent evolution in floral traits, temporal variation limits the strength and directionality of floral divergence (Waser et al. 1996; Caruso et al. 2003).

The present study evaluated quantitative and qualitative components of a flower-visitor system, and temporal variation of the assemblage of floral visitors (over 3 years) in three different populations of the narrow endemic milkwort, Polygala vayredae Costa (Polygalaceae). This species strictly depends on pollination vectors to set fruits, has been shown to suffer pollen limitation due to scarcity of pollinators (Castro et al. 2008b) and seems to be visited by insects with different contributions to pollination (Castro et al. 2008a). In particular, to understand how floral visitors determine the reproductive success of $P$. vayredae, the main objectives of this work were: (1) to determine the assemblage of floral visitors and to analyse the temporal variation in visitation patterns among populations of this plant species; (2) to assess the foraging behaviour of floral visitors, evaluating the type of visit, number of visited flowers, handling time and flight distances within and between patches; (3) to assess the effectiveness of floral visitors, evaluating their specific pollen depositions over the stigmas and presence of pollen over the insect body; and finally, (4) to determine if visitation rates by effective pollinators correlates with reproductive success of the populations studied.

\section{Materials and methods}

\section{Study species}

Polygala vayredae is a narrow endemic species from the Oriental pre-Pyrenees, where it occurs in a few populations distributed in approximately $12 \mathrm{~km}^{2}$, between 550 and 1,070 $\mathrm{m}$ a.s.l. It is a small perennial, spring flowering (April to May) shrub that forms dense clusters of hardly distinguishable individuals, as a result of a profuse production of shoots from a rootstock. The flowering ramets produce small axillary inflorescences with 1-3 papilionate flowers. The flowers are big [mean \pm SD (n): $16.2 \pm 0.9 \mathrm{~mm}$ (78)] when compared with other Polygala species, have a bright pink perianth and a yellow sulphur keel, and live for $8 \pm 1$ days (23). Nectar is produced at the base of the corolla tube [14.6 $\pm 0.8 \mathrm{~mm}$ long (78)], mainly during the first 3 days after anthesis of the flower (Castro et al. 2008a). Each flower produces $5,428 \pm 1,046$ pollen grains (10) that are presented to pollinators in a specialized region of the style (secondary pollen presentation; Castro et al. 2008c). The pistil results from the fusion of two monospermous carpels. P. vayredae is a xenogamous species with a self-incompatibility system operating at the stigmatic level; this plant depends on pollination vectors to produce fruits and was shown to have pollen limitation (Castro et al. 2008b). 
Study populations

The study was carried in Alta Garrotxa (Girona, Catalonia, Spain) during three consecutive springs (2005-2007) on the three main populations of $P$. vayredae: (1) Montmajor, 1,070 m, located in exposed rocky slopes with over 700 adult individuals $\left(42.2690^{\circ} \mathrm{N}, 2.4820^{\circ} \mathrm{W}\right)$; (2) Serrat dels Boixos, $750 \mathrm{~m}\left(42.2618^{\circ} \mathrm{N}, 2.4705^{\circ} \mathrm{W}\right)$, and (3) Colldecarrera, $630 \mathrm{~m}\left(42.2542^{\circ} \mathrm{N}, 2.4632^{\circ} \mathrm{W}\right)$, both located in mesophytic meadows with cultivated Pinus sylvestris with over 3,000 adult individuals.

Assemblage and foraging behaviour of floral visitors

The assemblage and behaviour of floral visitors were assessed by direct observations made in each population and year. The observations were performed during the flowering peak in several randomly selected patches of $2 \mathrm{~m}^{2}$. The observer was positioned at approximately $1 \mathrm{~m}$ from the patch being able to monitor all floral visitors without disturbing their foraging activity. Visits were recorded during $15 \mathrm{~min}$ census periods at different hours of the day (from 0800 to $1800 \mathrm{~h}, \mathrm{GMT})$. A total of 1,155 censuses evenly distributed per population and year were performed, corresponding to a total $289 \mathrm{~h}$ of observation. During each census the following variables were registered with a voice recorder: visiting species and type of visit (see below), total number of flowers visited per patch, handling time and foraging distances within and between patches. The foraging distances within the patch were recorded by marking the first flowers visited by the insect with a known sequence of colours (without disturbing its behaviour) and later measuring the distance between them; the foraging distances between patches were recorded only at the end of the census by following the insects that left the patch. The number of open flowers in each patch was recorded every day.

The floral visitors were characterized as legitimate visitors when entering the corolla through the corolla tube or as illegitimate visitors when accessing the nectar through other means. Illegitimate visitors were classified as nectar robbers, secondary nectar robbers or nectar thieves, following Inouye (1980). Moreover, among the legitimate visitors, those unable to move the keel downwards (and consequently not coming in contact with the reproductive organs; for illustrations see Castro et al. 2008c) were classified as ineffective legitimate visitors. Specimens of each floral visitor were collected to confirm their identification, to observe pollen over the insect body and to perform morphometric analyses (voucher specimens deposited at the CFE, University of Coimbra).

\section{Effectiveness of floral visitors}

Several components of visitor effectiveness were analysed for each visitor species, namely: (1) frequency of interaction; (2) presence of pollen over the insect body and (3) per-visit pollen deposition (Herrera 1989; Gómez and Zamora 1999) and pollen tube development. The frequency of interactions was calculated for $15 \mathrm{~min}$ by multiplying insect abundance (number of insects per $15 \mathrm{~min}$ ) by flower visitation rate (number of flowers visited per $15 \mathrm{~min}$; Herrera 1989). The presence of pollen over the insect body was evaluated under a stereo microscope. The pollen of $P$. vayredae is big [polar axis: $45.6 \pm 1.6 \mu \mathrm{m}$ (36)] and typically polyzonocolporate and thus, was easily recognisable (Castro et al. 2009b). Measurements of proboscis and body length of the insect were also taken under a stereo microscope using an ocular micrometre.

The amount of pollen deposited over the stigma by each floral visitor was evaluated on the patches of the censuses by emasculating and bagging up to 300 randomly selected flower buds. After bud opening and during the census, flowers were unbagged and monitored. Immediately after receiving a visit, the flowers were bagged, identified with the floral visitor and collected in ethanol $70 \%$ after 24 h (3-30 flowers/ floral visitor). Preliminary tests in this species showed that $24 \mathrm{~h}$ is sufficient time for the successful development of the pollen tubes to the ovary. At the laboratory, pistils were softened with sodium hydroxide $8 \mathrm{~N}$ for $4 \mathrm{~h}$, stained with aniline blue $(0.05 \%$ overnight) and squashed in a drop of $50 \%$ glycerine (Dafni et al. 2005). Finally, they were observed through a Nikon Eclipse 80i epifluorescence microscope equipped with a UV-2A filter cube (330-380 nm excitation) and the total number of pollen grains over the stigma and of pollen tubes at the end of the style were assessed. 
Reproductive success

The reproductive success was assessed using two different measures, (1) percentage of flowers receiving a visit from an effective pollinator, and (2) fruit production under natural open pollination. The percentage of flowers receiving a visit by an effective floral visitor was determined for each census (15 min), through the ratio between the total number of flowers visited by effective pollinators by the total number of flowers under observation during the census. Fruit production was assessed in up to 220 flowers in each population and year and calculated as the percentage of developed fruits from the total number of flower marked.

\section{Statistical analyses}

The variation in abundance of floral visitors among populations, years and type of visitor (effective pollinator vs. ineffective visitors) was analysed using Generalized Linear Models (GLZ), with the dependent variable (i.e., visitor abundance) adjusted to a Poisson distribution and a logarithmic link function for model responses. The Type 3 Likelihood Ratio test of effects was computed. Differences in floral visitor composition among population and years were also explored using a two-way non-parametric MANOVA, with population and year as factors and pollinator species as variables and using Bray-Curtis distance (Anderso 2001).

For each insect species, descriptive statistics were calculated for proboscis size, length of the body, number of visited flowers per patch, handling time, flight distances, visitation rate, frequency of interaction and pollen deposited in the stigmatic papillae per visit. Differences in number of visited flowers per patch, handling time, flight distances within patch and number of pollen tubes were also analysed using a Kruskal-Wallis one-way ANOVA on ranks considering only legitimate effective pollinators, followed by pairwise multiple comparisons using the Dunn's method. The number of pollen grains deposited on the stigma by each effective legitimate pollinator was analysed with a one-way ANOVA and the flight distances between patches with a Mann-Whitney Rank Sum Test.

Differences in fruit set among populations and years were analysed using GLZ, with fruit set approximated to a binomial distribution and a logit link function for model responses. The Type 3 Likelihood Ratio test of effects was computed. Correlations among fruit set and the probability to receive a visit from an effective pollinator regardless of population and year were assessed through a Pearson correlation.

All the statistical analyses were performed using the STATISTICA 7 software (StatSoft. Inc., Tulsa, Oklahoma, USA) except the non-parametric MANOVA that was done in PAST software (Hammer and Harper, version 2.17b; Hammer et al. 2001).

\section{Results}

Assemblage of floral visitors

During the 3 years of study and across three populations a total number of 21,839 floral visitor interactions performed by 967 individuals were observed, with the flowers of $P$. vayredae being visited by a diverse and variable array of insects ("Appendix 1"). At least 27 insect species belonging to orders Hymenoptera $(59.3 \%$ of the total species), Lepidoptera $(37.0 \%)$ and Diptera $(3.7 \%)$ were observed. The most abundant species was Bombus terrestris, which accounted for $64.2 \%$ of the overall floral visits, followed by B. pascuorum (16.8\%), Macroglossum stellatarum (5.2\%) and Anthophora sp. (4.7\%) (Fig. 1). The remaining 23 species contributed with only $9.1 \%$ of the total number of visits (Fig. 1; “Appendix 1").

Significant differences in the abundance of insects among factors (year, population and visitor type) and in their interactions were observed (Table 1). Overall, the abundance of insects was lower in 2006 in any population, and in Montmajor population in general (Fig. 1e). Both effective pollinators and ineffective floral visitors were observed and their abundance also varied significantly, with ineffective visitors (i.e., nectar robbers, secondary nectar robbers, nectar thieves and legitimate ineffective visitors) being more abundant than effective pollinators in the majority of populations and years (Fig. 1f). Floral visitor composition also varied significantly among population and years $\left(F_{2,1034}=14.71, \quad P<0.001\right.$ and $F_{2,1034}=$ 11.76, $P<0.001$, respectively) and in their interactions $\left(F_{4,1034}=-52.61, P<0.001\right)$. 

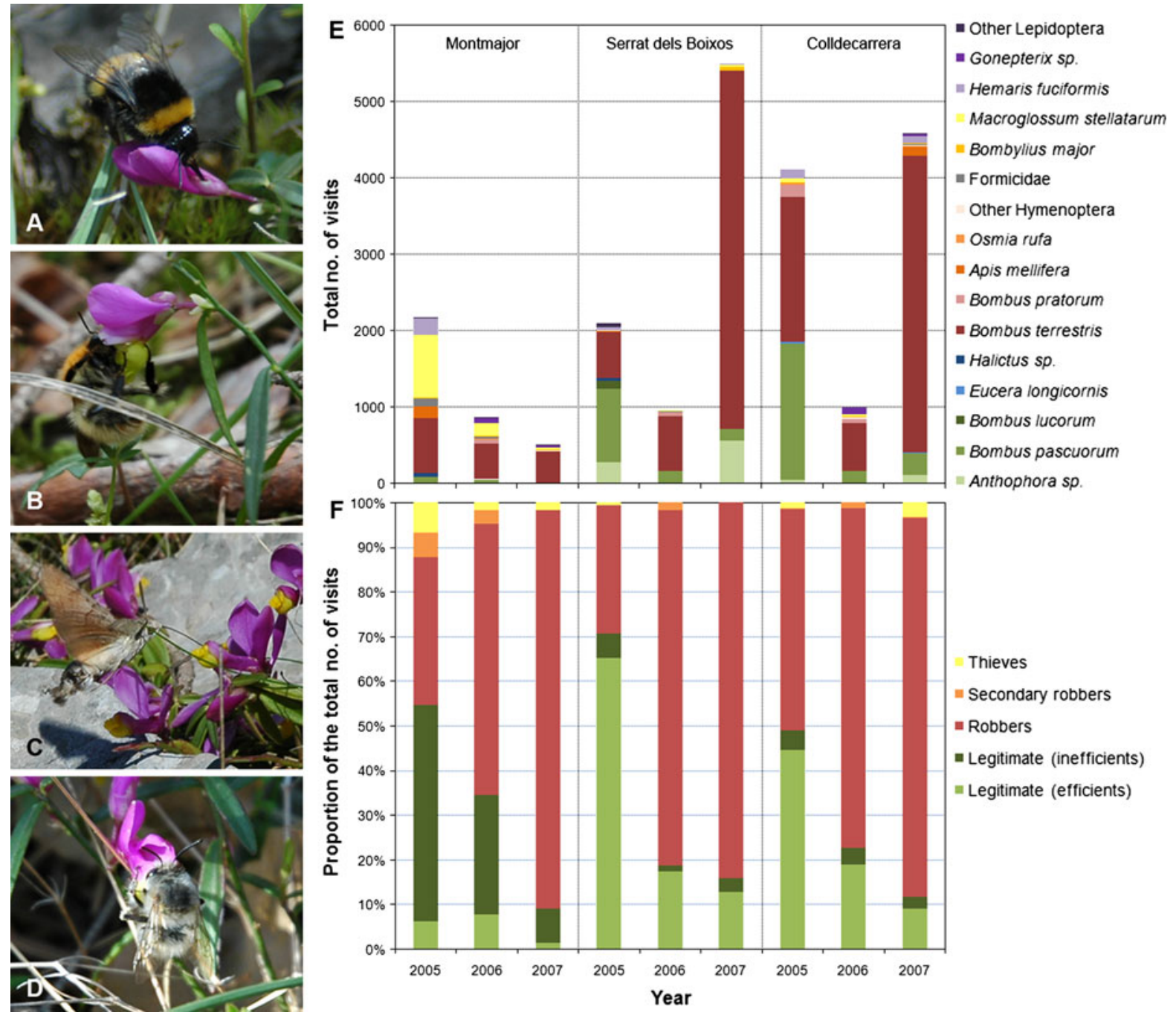

Fig. 1 Floral visitors of $P$. vayredae flowers: a B. terrestris, $\mathbf{b}$ B. pascuorum, $\mathbf{c}$ M. stellatarum, $\mathbf{d}$ Anthophora sp., e spatial and temporal variation in the assemblage of floral visitors, and $\mathbf{f}$ spatial and temporal variation in the type of floral visitor

Table 1 Results of the generalized linear model analysis for the comparison of abundance of effective pollinators and ineffective visitors (number of insects observed per $15 \mathrm{~min}$ ) among different populations and years in P. vayredae

\begin{tabular}{llrl}
\hline Effect & df & \multicolumn{1}{c}{$\chi^{2}$} & \multicolumn{1}{l}{$P$} \\
\hline Year & 2 & 54.98 & $<0.001$ \\
Population & 2 & 56.43 & $<0.001$ \\
Visitor & 1 & 165.90 & $<0.001$ \\
Year $\times$ population & 4 & 57.66 & $<0.001$ \\
Year $\times$ visitor & 2 & 30.21 & $<0.001$ \\
Population $\times$ visitor & 2 & 30.61 & $<0.001$ \\
Year $\times$ population $\times$ visitor & 4 & 5.64 & 0.228 \\
\hline
\end{tabular}

Foraging behaviour of floral visitors

The floral visitors presented different foraging behaviours when facing the flowers, with the majority of them seeking nectar (the exception being the pollinivorous species, Eucera longicornis and Halictus sp.). Of the 27 species, only $18.5 \%$ were effective legitimate pollinators (see also results below), with the remaining $81.5 \%$ of the species acting as ineffective legitimate visitors (29.6\%; e.g., the majority of Lepidoptera and Bombylius sp.), nectar robbers (22.3\%; e.g., B. terrestris and B. pratorum), nectar thieves (18.5\%; e.g., Apis mellifera), or secondary 
nectar robbers (11.1\%; e.g., Formicidae) (Fig. 1; "Appendix 1").

Anthophora sp. and B. pascuorum had the longest proboscis (excluding Lepidoptera) and robust bodies, enabling them to trigger the flower and reach the nectar (Fig. 1b, d). E. longicornis and Halictus sp., when foraging for pollen, exposed the stigmatic region, being directly involved in pollination due to the close proximity between the site of pollen presentation and the stigmatic papillae (Castro et al. 2008c). Despite its relatively short proboscis, in comparison with the length of the corolla tube, B. lucorum behaved as a legitimate visitor. Unfortunately, due to its scarcity it was difficult to thoroughly evaluate if this species always behaved as a pollinator or if it changes its behaviour towards nectar robber. The remaining visitors were incapable of reaching nectar in a legitimate way, mainly due to their short mouth parts or light bodies, behaving as primary nectar robbers (piercing the base of the corolla where nectar is accumulated; Fig. 1a), secondary robbers (e.g., Formicidae, used the existing holes to collect nectar), or nectar thieves (e.g., Lepidoptera and Bombylius sp., made legitimate visits, but their long and thin proboscis, associated with light bodies, enabled them to reach the nectar without triggering the flower; Fig. 1c).

The behavioural analysis of the effective legitimate pollinators revealed significant differences between the insects for the number of flowers visited per patch $\left(H_{4}=25.1, P<0.001\right)$, handling time $\left(H_{4}=61.8, P<\right.$ $0.001)$, flight distances within $\left(H_{4}=17.9, P=0.001\right)$ and between the patches $\left(T=488.0, \mathrm{n}_{\text {Anthophora }}=24\right.$, $\mathrm{n}_{B . \text { pascuorum }}=16, P<0.001$ ). Overall, the differences were consistent with the two foraging strategies observed: the nectar-collecting B. pascuorum, Anthophora sp. and $B$. lucorum visited a significantly larger number of flowers per patch, spent less time per flower and moved for shorter distances within the patches, when compared with the pollen-collecting species, E. longicornis and Halictus sp. $(P<0.05$; Table 2). Between patches, Anthophora sp. moved to significantly shorter distances than $B$. pascuorum $(P<0.05)$ whereas B. lucorum, E. longicornis and Halictus sp. quickly vanished from observer sight, presumably moving beyond a measurable distance.

\section{Effectiveness of floral visitors}

The floral visitors with higher frequency of interactions were $B$. terrestris, $B$. pascuorum, $M$. stellatarum and Anthophora sp. (Table 3). The nectar robber $B$. terrestris was always among the insects with the highest frequencies of interaction, while the other three floral visitors were among the insects with the highest frequencies of interaction only in some years or populations (Table 3 ).

Pollen of $P$. vayredae was only found on the body of four effective legitimate pollinator species. The remaining floral visitors did not carry pollen over their bodies nor deposited pollen in the stigmas. No significant differences were observed in the amount of pollen deposited over the stigmatic papillae $\left(F_{3,58}=0.840, P=0.478\right)$ and in the number of pollen tubes at the end of the style $\left(H_{3}=5.251\right.$, $P=0.154)$ after one visit by effective pollinators. On average, the pollinators deposited $110 \pm 73$ pollen grains after one visit and $3.5 \pm 4.5$ pollen tubes reached the end of the style (Table 2).

\section{Reproductive success}

The female fitness measured as fruit set varied significantly among years $\left(\chi_{2}^{2}=36.20, P<0.001\right)$ and populations $\left(\chi_{2}^{2}=130.32, P<0.001\right)$ (Table 4$)$. Usually, the highest values of fruit production were observed in Colldecarrera, while the lowest ones were from Montmajor. Within each population, female fitness was higher during 2005, while the lowest values were usually from 2007.

Overall, the probability of a flower of $P$. vayredae to receive a visit from an effective pollinator in a 15 min period was variable (Table 4). Positive correlations were obtained between the percentage of flowers receiving an effective visit and the female fitness $\left(R^{2}=0.709, P=0.033\right.$; Table 4$)$. Nonetheless, unexpectedly, in Serrat dels Boixos the low probability of receiving an effective visit obtained in 2006 resulted in the second highest value of fruit set for that site.

\section{Discussion}

The reproductive success of $P$. vayredae depends upon effective pollination by insects that move pollen between different plants (Castro et al. 2008b). During our 3-year study, flowers of $P$. vayredae were visited by a moderately diverse array of floral visitors mainly composed of Hymenoptera and Lepidoptera. The attractive flowers of 


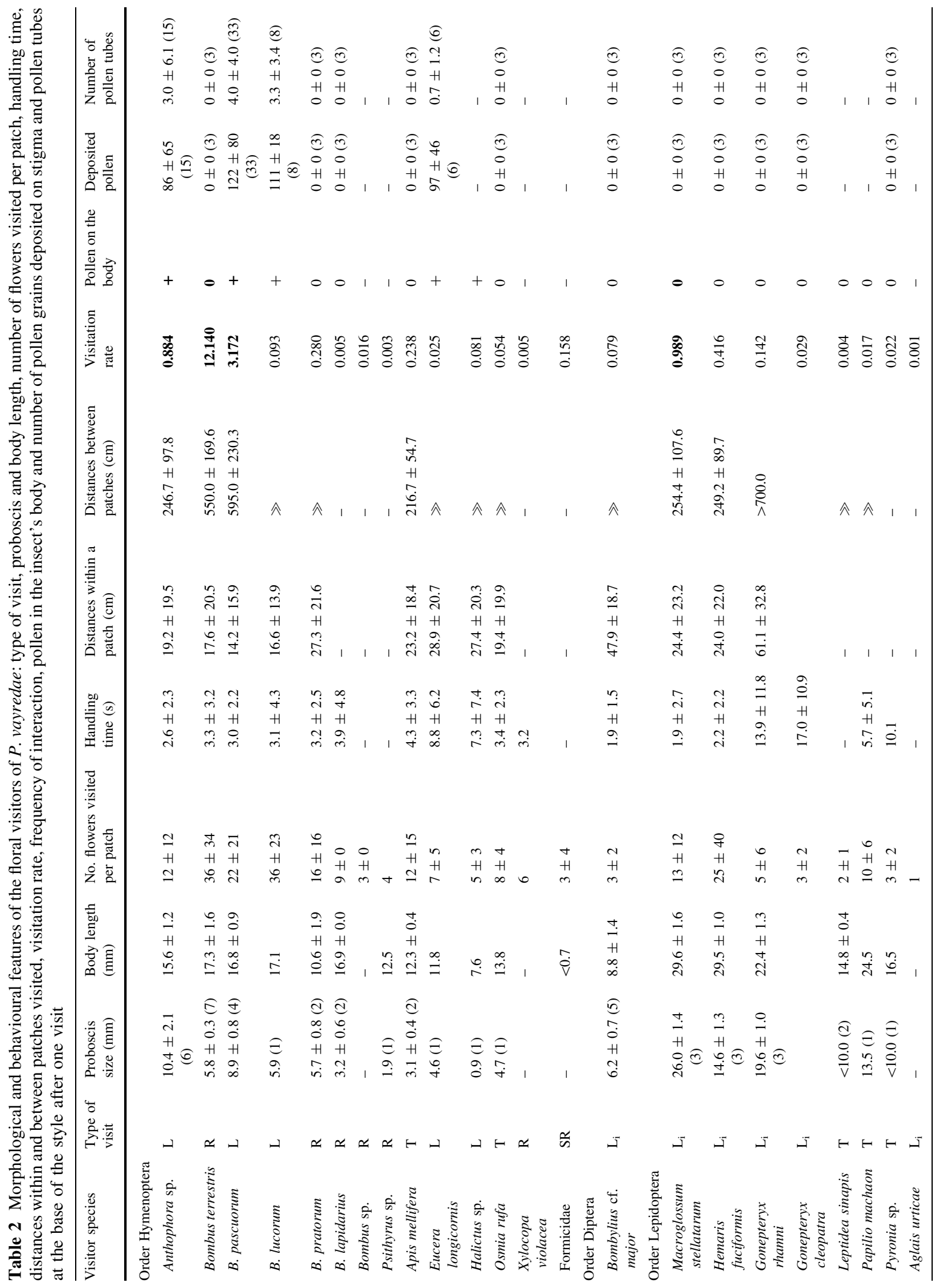




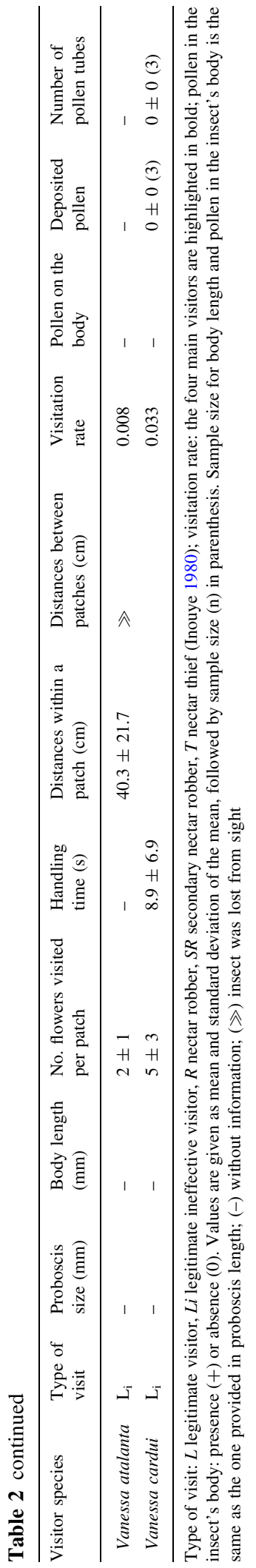

this species not only caught the attention of pollinators, but also of a large number of larcenists (i.e., ineffective visitors exploiting nectar rewards). No larcenists were involved in pollination and, consequently, legitimate pollinators were restricted to four species, from which two (the long-tongued B. pascuorum and Anthophora sp.) were predominantly more abundant than the others (the pollinivorous Halictus sp. and E. longicornis). The effectiveness of floral visitors in pollen transfer was determined by floral features that restricted access to floral rewards and sexual structures. These results reinforce the need to perform observations focused on the behaviour and effectiveness of floral visitors to properly assess the effective pollinators of a plant species (e.g., Pellmyr and Thompson 1996; Navarro et al. 2008).

Assemblage and temporal variation of floral visitors

We also documented temporal variation in floral visitor abundance and community composition among the populations. Pollinators were generally scarce, in contrast to larcenists that were a constant feature in all the populations and years studied. A similar pattern has been observed in other insect pollinated species (e.g., Herrera 1988; Fenster and Dudash 2001; Artz et al. 2010) and has clear effects on the visitation rates by pollinators and on the reproductive success of plants in the populations each year. While in Serrat dels Boixos and Colldecarrera at least one legitimate pollinator species could be regularly found visiting the flowers, in Montmajor, the visitation rates of pollinators were always extremely low leading to a significantly lower fruit production in this population. The temporal variation in insect abundance and diversity observed over the 3 years could be explained, for example, by differences in abiotic factors. It has been previously shown that pollinator services are linked not only with the available resources within the population but also with the activity and population size of the pollinators, which are regulated by environmental factors such as temperature, relative humidity, solar radiation and/or wind (e.g., Herrera 1993; Vicens and Bosch 2000).

Despite the close geographical proximity (c. $1.5-2.5 \mathrm{~km}$ ), abundance of floral visitors and community composition varied significantly between the study sites. Such differences among populations may arise from microhabitat selection by pollinators, which 
Table 3 Frequency of interaction (insect abundance * flower visitation rate) between $P$. vayredae and its floral visitors in the three studied populations and in three different years

\begin{tabular}{|c|c|c|c|c|c|c|c|c|c|c|}
\hline & \multirow[t]{2}{*}{ Type of visit } & \multicolumn{3}{|c|}{ Montmajor } & \multicolumn{3}{|c|}{ Serrat dels Boixos } & \multicolumn{3}{|c|}{ Colldecarrera } \\
\hline & & 2005 & 2006 & 2007 & 2005 & 2006 & 2007 & 2005 & 2006 & 2007 \\
\hline Anthophora sp. & $\mathrm{L}$ & & $<0.001$ & & 0.492 & & 1.878 & 0.007 & 0.001 & 0.196 \\
\hline Bombus terrestris & $\mathrm{R}$ & 1.072 & 0.840 & 0.543 & 2.083 & 2.001 & 34.690 & 2.157 & 0.860 & 42.253 \\
\hline B. pascuorum & $\mathrm{L}$ & 0.022 & 0.025 & & 3.959 & 0.222 & 0.178 & 2.423 & 0.088 & 0.744 \\
\hline B. lucorum & $\mathrm{L}$ & & & & 0.030 & & & & & \\
\hline B. pratorum & $\mathrm{R}$ & & 0.013 & & 0.002 & 0.028 & & 0.011 & 0.011 & \\
\hline Apis mellifera & $\mathrm{T}$ & 0.126 & & 0.001 & $<0.001$ & & & & & 0.060 \\
\hline Eucera longicornis & $\mathrm{L}$ & & & & & & & $<0.001$ & & 0.003 \\
\hline Halictus sp. & $\mathrm{L}$ & 0.040 & & $<0.001$ & 0.026 & & & & & \\
\hline Osmia rufa & $\mathrm{T}$ & & 0.002 & & $<0.001$ & & & 0.002 & & 0.002 \\
\hline Other Hymenoptera & $\mathrm{R}$ & & $<0.001$ & & & & 0.003 & $<0.001$ & & 0.002 \\
\hline Formicidae & SR & 0.138 & 0.042 & & & 0.019 & & $<0.001$ & 0.009 & 0.006 \\
\hline Bombylius cf. major & $\mathrm{L}_{\mathrm{I}}$ & 0.001 & 0.002 & 0.002 & & & 0.016 & $<0.001$ & $<0.001$ & 0.012 \\
\hline Macroglossum stellatarum & $\mathrm{L}_{\mathrm{I}}$ & 2.723 & 0.217 & 0.011 & & 0.002 & 0.006 & 0.001 & 0.002 & \\
\hline Hemaris fuciformis & $\mathrm{L}_{\mathrm{I}}$ & 0.100 & & & 0.004 & & 0.002 & 0.010 & & 0.013 \\
\hline Gonepteryx sp. & $\mathrm{L}_{\mathrm{I}}$ & $<0.001$ & & & 0.081 & & 0.159 & 0.002 & & 0.011 \\
\hline Other Lepidoptera & $\mathrm{L}_{\mathrm{I}} / \mathrm{T}$ & $<0.001$ & 0.031 & & 0.002 & & & 0.002 & & 0.010 \\
\hline
\end{tabular}

The frequency of interaction of the two main floral visitors in each population is highlighted in bold. Empty cells represent zero interactions between $P$. vayredae flowers and the floral visitor

Type of visit $L$ legitimate visitor, $L i$ legitimate ineffective visitor, $R$ nectar robber, $S R$ secondary nectar robber, $T$ nectar thief (Inouye 1980); visitation rate: the four main visitors are highlighted in bold

Table 4 Fruit production and percentage of flowers of $P$. vayredae receiving a visit by an effective pollinator in a $15 \mathrm{~min}$ period for the studied populations and years

\begin{tabular}{llcc}
\hline Population & Years & $\begin{array}{l}\text { Fruit } \\
\text { set }\end{array}$ & $\begin{array}{l}\text { Percentage of } \\
\text { effective visits }\end{array}$ \\
\hline Montmajor & $2005^{*}$ & 7.4 & $0.6 \pm 2.1(140)$ \\
& 2006 & 3.0 & $0.2 \pm 0.8(108)$ \\
Serrat dels Boixos & 2007 & 1.9 & $0.01 \pm 0.1(102)$ \\
& $2005^{*}$ & 28.9 & $5.6 \pm 8.7(103)$ \\
Colldecarrera & 2006 & 22.3 & $0.7 \pm 2.2(108)$ \\
& 2007 & 14.8 & $1.5 \pm 2.9(104)$ \\
& $2005^{*}$ & 47.6 & $3.1 \pm 8.2(264)$ \\
& 2006 & 21.0 & $1.1 \pm 4.1(143)$ \\
& 2007 & 26.0 & $2.7 \pm 7.5(76)$ \\
\hline
\end{tabular}

Fruit set is the percentage of flowers developing into fruit; the proportion of effective visits is given in percentage as mean and standard deviation of the mean followed by sample size in parenthesis; *Data from 2005 were obtained from Castro et al. (2008a)

include variation in food resources for insects, plant traits and/or microclimatic aspects, among others (Herrera 1988; Gómez and Zamora 1999; Navarro
2000; Herrera et al. 2002). Indeed, there were marked ecological differences between the study sites that could affect the spectrum, abundance and behaviour of pollinators. The population of Montmajor is a sunexposed and windy population located in a rocky face at higher altitude and presented a distinctive vegetation cover and floristic composition, with a wider diversity of flowering species than the other two populations. Competition or facilitation by other coflowering species has been shown to play a major role in plant-animal interactions for other insect pollinated plants (e.g., Ghazoul 2006); in Montmajor, P. vayredae flowered synchronously with other species resulting in competition for pollinators (S. Castro, unpublished data), whereas in the other populations, $P$. vayredae flowered alone being the main food resource available for floral visitors.

Nectar robbing and its consequences

Due to the large incidence of larcenists, nectar robbing was frequently observed in all populations (results 
herein and Castro et al. 2008a). Similar observations have been made in several other nectar rewarding species, with nectar robbing playing, in many cases, an important role in further plant-animal interactions. These studies showed that nectar robbers may have direct or indirect positive (e.g., Navarro et al. 1993; Navarro 2000), neutral (e.g., Arizmendi et al. 1996) or negative effects (e.g., Irwin and Brody 1999; Navarro 2001; Zhang et al. 2007) in plant reproductive outcome. In $P$. vayredae nectar robbers had no positive effect in the reproductive success of $P$. vayredae as they do not take part in pollination. In this species nectar robbers have been shown to change the behaviour of legitimate pollinators, leading to significant negative effects on plant fecundity, through both male and female functions (Castro et al. 2008c), and potentially driving an indirect selection over certain floral traits (Castro et al. 2009c; Navarro and Medel 2009). Consequently, considering their abundance in $P$. vayredae populations, larcenists play a major role in the biology of this plant.

\section{Pollinator behaviour and plant reproductive} success

When searching for food, insects come across a variable assemblage of flowers and rewards patchily distributed in time and space. Facing this variable scenario, insects evolved an array of foraging strategies to fulfil their needs that can have major implications for the reproductive success of the plants they exploit (Goulson 2000). The pollinators of $P$. vayredae presented two distinct foraging strategies: while nectarivorous species confidently exploited a large number of flowers, moving between neighbouring ramets and spending less time per flower; pollinivorous species visited fewer flowers, moving to ramets located at large distances, but spent more time per flower as they usually entered the corolla several times during pollen collection. Similar behaviour of pollinivorous insects has also been observed in other systems (e.g., Gómez and Zamora 1999), and might be involve with promotion of gene flow to greater distances than the ones achieved by nectarivorous insects. Still, in P. vayredae, the different behaviour of pollinators appears not to influence their efficiency on plant female function, since similar amounts of pollen were deposited over the stigmas and similar number of pollen tubes developed in the style after one visit.
However, pollinivorous insects may detrimentally affect the male fitness by reducing the amount of pollen available in flowers (Hargreaves et al. 2009) and, in the particular case of $P$. vayredae, by promoting self-pollen deposition and stigmatic clogging due to the close proximity of male and female structures (Castro et al. 2008b). The latter effects can result in pollen of lower quality being delivered to the stigmas.

The present study shows that one of the major factors leading to pollen limitation previously reported in P. vayredae (Castro et al. 2008b) is the scarcity, unpredictability and/or behavioural patterns of effective pollinators. Pollen limitation has been described as a widespread feature among animal pollinated species, commonly compromising seed production in plant populations (reviewed in Knight et al. 2005). While most studies account for just the "quantitative" component (i.e., stigmas receiving fewer pollen grains than the necessary for optimal ovule fertilization), the "quality" component of pollen limitation only recently has been taken into account, as well (Aizen and Harder 2007). In our study, the need for a visit of a pollinator for pollen deposition on the stigma demonstrates the importance of the quantitative component of pollen limitation in $P$. vayredae. However, the contrast between the large number of pollen grains delivered to the stigma by legitimate visitors and the low number of pollen tubes at the base of the style, emphasises that many pollen grains may not be suitable for fertilization. Thus, the qualitative aspect of pollen limitation may also be an important factor determining the reproductive success of this species.

\section{Conclusion}

The present study revealed temporal and among populations variability in the floral visitors of $P$. vayredae. A large assemblage of floral visitors, mainly composed of larcenists and few legitimate pollinators, was observed. As a consequence, the plant reproductive outcome was low and significantly variable among populations and years. These observations clearly reveal the need for studies at a spatial and temporal scale that will enable a full assessment of the spectrum of pollinators, as well as, the nature of plantanimal interactions. This type of study provides relevant information on plant pollination ecology 
and important details for the implementation of conservation strategies for this endemic milkwort with a restricted distribution.

Acknowledgments Authors thank the Departamento de Medi Ambient of Generalitat de Cataluña and the Consorsi d'Alta Garrotxa for allowing this research and to Parc Natural de la Zona Volcànica de la Garrotxa for all the support during field seasons. Authors are grateful to Irina Stanescu for the assistance during 2006 field season and to José M. Gómez for the invaluable help with data analysis and comments during manuscript preparation. Authors are also grateful to the Associate Editor and two anonymous reviewers for the helpful comments to the manuscript. The Portuguese Foundation for
Science and Technology financed the work of Sílvia Castro (FCT/BD/10901/2002 and FCT/BPD/41200/2007). Victoria Ferrero was funded by a Xunta de Galicia postdoctoral contract. The work was partially financed under the grants from the Xunta de Galicia (INCITE09-3103009PR), CGL200910466 of the Spanish Dirección General de Investigación, Ciencia y Tecnologíca (DGICYT) and FEDER funds from the European Union to Luis Navarro.

\section{Appendix 1}

See Table 5.

Table 5 Number of interactions between P. vayredae and its floral visitors in the three populations studied during 2005,2006 and 2007

\begin{tabular}{|c|c|c|c|c|c|c|c|c|c|c|}
\hline \multirow[t]{2}{*}{ Visitor species } & \multirow{2}{*}{$\begin{array}{l}\text { Type of } \\
\text { visit }\end{array}$} & \multicolumn{3}{|c|}{ Montmajor } & \multicolumn{3}{|c|}{ Serrat dels Boixos } & \multicolumn{3}{|c|}{ Colldecarrera } \\
\hline & & 2005 & 2006 & 2007 & 2005 & 2006 & 2007 & 2005 & 2006 & 2007 \\
\hline \multicolumn{11}{|l|}{ Order Hymenoptera } \\
\hline $\begin{array}{l}\text { Anthophora sp. } \\
\text { (Anthophoridae) }\end{array}$ & $\mathrm{L}$ & & $4(0.5)$ & & $\begin{array}{l}277 \\
(13.0)\end{array}$ & & $\begin{array}{l}564 \\
\quad(10.1)\end{array}$ & $57(1.4)$ & $8(0.9)$ & $\begin{array}{l}111 \\
(2.4)\end{array}$ \\
\hline $\begin{array}{l}\text { Bombus terrestris } \\
\text { (Apidae) }\end{array}$ & $\mathrm{R}$ & $\begin{array}{l}724 \\
(33.6)\end{array}$ & $\begin{array}{l}466 \\
\quad(56.1)\end{array}$ & $\begin{array}{l}421 \\
\quad(90.1)\end{array}$ & $\begin{array}{l}603 \\
(28.4)\end{array}$ & $\begin{array}{l}712 \\
(73.7)\end{array}$ & $\begin{array}{l}4690 \\
(83.7)\end{array}$ & $\begin{array}{l}1903 \\
(45.8)\end{array}$ & $\begin{array}{l}620 \\
(69.1)\end{array}$ & $\begin{array}{l}3883 \\
(84.5)\end{array}$ \\
\hline $\begin{array}{l}\text { Bombus pascuorum,queen } \\
\text { (Apidae) }\end{array}$ & $\mathrm{L}$ & $\begin{array}{l}87 \\
\quad(4.0)\end{array}$ & $\begin{array}{l}51 \\
\quad(6.1)\end{array}$ & & $\begin{array}{l}964 \\
\quad(45.3)\end{array}$ & $\begin{array}{l}164 \\
(17.4)\end{array}$ & $\begin{array}{l}160 \\
(2.9)\end{array}$ & $\begin{array}{l}1778 \\
(42.8)\end{array}$ & $\begin{array}{l}162 \\
\quad(18.1)\end{array}$ & $\begin{array}{l}294 \\
(6.4)\end{array}$ \\
\hline Bombus lucorum (Apidae) & $\mathrm{L}$ & & & & $\begin{array}{r}107 \\
(5.0)\end{array}$ & & & & & \\
\hline $\begin{array}{l}\text { Bombus pratorum } \\
\text { (Apidae) }\end{array}$ & $\mathrm{R}$ & & $\begin{array}{l}42 \\
(5.1)\end{array}$ & & $8(0.4)$ & $\begin{array}{l}56 \\
(5.8)\end{array}$ & & $\begin{array}{l}156 \\
(3.8)\end{array}$ & $\begin{array}{l}61 \\
(6.8)\end{array}$ & \\
\hline $\begin{array}{l}\text { Bombus lapidarius } \\
\text { (Apidae) }\end{array}$ & $\mathrm{R}$ & & $3(0.4)$ & & & & & & & 3 \\
\hline $\begin{array}{l}\text { Bombus hortorum } \\
\text { (Apidae) }\end{array}$ & $\mathrm{R}$ & & & & & & $18(0.3)$ & & & \\
\hline Psithyrus sp. (Apidae) & $\mathrm{R}$ & & & & & & & & & ${ }^{4}(<0.1)$ \\
\hline Apis mellifera (Apidae) & $\mathrm{T}$ & $\begin{array}{l}145 \\
(6.7)\end{array}$ & & $8(1.7)$ & $3(0.1)$ & & & & & $\begin{array}{l}119 \\
(2.6)\end{array}$ \\
\hline $\begin{array}{l}\text { Eucera longicornis } \\
\text { (Apidae) }\end{array}$ & $\mathrm{L}$ & & & & & & & $19(0.5)$ & & $10(0.2)$ \\
\hline Halictus sp. (Halictidae) & $\mathrm{L}$ & $\begin{array}{l}52 \\
(2.4)\end{array}$ & & $2(0.4)$ & $\begin{array}{l}40 \\
(1.8)\end{array}$ & & & & & \\
\hline $\begin{array}{l}\text { Osmia rufa } \\
\text { (Megachilidae) }\end{array}$ & $\mathrm{T}$ & & $\begin{array}{l}14 \\
(1.7)\end{array}$ & & $5(0.2)$ & & & $31(0.7)$ & & $12(0.3)$ \\
\hline $\begin{array}{l}\text { Xylocopa violacea } \\
\text { (Xylocopidae) }\end{array}$ & $\mathrm{R}$ & & & & & & & $6(0.1)$ & & \\
\hline $\begin{array}{l}\text { Formica gagates } \\
\text { (Formicidae) }\end{array}$ & SR & $5(0.2)$ & $1(0.1)$ & & & $4(0.4)$ & & 2 & $\begin{array}{l}10 \\
(1.1)\end{array}$ & 4 \\
\hline $\begin{array}{l}\text { Temnothorax sp. } \\
\text { (Formicidae) }\end{array}$ & SR & $2(0.1)$ & $4(0.5)$ & & & $\begin{array}{l}12 \\
(1.2)\end{array}$ & & & $1(0.1)$ & $\begin{array}{l}3 \\
(<0.1)\end{array}$ \\
\hline Myrmica sp. (Formicidae) & SR & & $3(0.4)$ & & & & & & $1(0.1)$ & \\
\hline
\end{tabular}


Table 5 continued

\begin{tabular}{|c|c|c|c|c|c|c|c|c|c|c|}
\hline \multirow[t]{2}{*}{ Visitor species } & \multirow{2}{*}{$\begin{array}{l}\text { Type of } \\
\text { visit }\end{array}$} & \multicolumn{3}{|c|}{ Montmajor } & \multicolumn{3}{|c|}{ Serrat dels Boixos } & \multicolumn{3}{|c|}{ Colldecarrera } \\
\hline & & 2005 & 2006 & 2007 & 2005 & 2006 & 2007 & 2005 & 2006 & 2007 \\
\hline Unknown (Formicidae) & SR & $\begin{array}{r}111 \\
(5.2)\end{array}$ & $\begin{array}{l}18 \\
(2.2)\end{array}$ & & & & & & & ${ }^{1}(<0.1)$ \\
\hline \multicolumn{11}{|l|}{ Order Diptera } \\
\hline $\begin{array}{l}\text { Bombylius cf. major } \\
\text { (Bombyliidae) }\end{array}$ & $\mathrm{L}_{\mathrm{i}}$ & $7(0.3)$ & $\begin{array}{l}12 \\
(1.4)\end{array}$ & $8(1.7)$ & & & $44(0.8)$ & $5(0.1)$ & $2(0.2)$ & $13(0.3)$ \\
\hline \multicolumn{11}{|l|}{ Order Lepidoptera } \\
\hline $\begin{array}{l}\text { Macroglossum stellatarum } \\
\text { (Sphingidae) }\end{array}$ & $\mathrm{L}_{\mathrm{i}}$ & $\begin{array}{l}821 \\
(38.2)\end{array}$ & $\begin{array}{l}166 \\
(20.0)\end{array}$ & $\begin{array}{l}28 \\
(6.0)\end{array}$ & & $\begin{array}{l}14 \\
(1.4)\end{array}$ & $32(0.6)$ & $49(1.2)$ & $\begin{array}{l}32 \\
(3.6)\end{array}$ & \\
\hline $\begin{array}{l}\text { Hemaris fuciformis } \\
\text { (Sphingidae) }\end{array}$ & $\mathrm{L}_{\mathrm{i}}$ & $\begin{array}{l}217 \\
\quad(10.1)\end{array}$ & & & $\begin{array}{l}41 \\
\quad(1.9)\end{array}$ & & $8(0.1)$ & $\begin{array}{l}116 \\
(2.8)\end{array}$ & & $99(2.2)$ \\
\hline $\begin{array}{l}\text { Gonepteryx rhamni } \\
\text { (Pieridae) }\end{array}$ & $\mathrm{L}_{\mathrm{i}}$ & $6(0.3)$ & & & $\begin{array}{l}66 \\
(3.1)\end{array}$ & & $68(1.2)$ & $13(0.3)$ & & $11(0.2)$ \\
\hline $\begin{array}{l}\text { Gonepteryx cleopatra } \\
\text { (Pieridae) }\end{array}$ & $\mathrm{L}_{\mathrm{i}}$ & & & & $6(0.3)$ & & $18(0.3)$ & $4(0.1)$ & & $6(0.1)$ \\
\hline Leptidea sinapis (Pieridae) & $\mathrm{T}$ & & & & & & & & & $5(0.1)$ \\
\hline $\begin{array}{l}\text { Papilio machaon } \\
\text { (Papilionidae) }\end{array}$ & $\mathrm{T}$ & & & & & & & $6(0.1)$ & & $14(0.3)$ \\
\hline $\begin{array}{l}\text { Pyronia sp. } \\
\text { (Nymphalidae) }\end{array}$ & $\mathrm{T}$ & $2(0.1)$ & & & $6(0.3)$ & & & $17(0.4)$ & & \\
\hline $\begin{array}{l}\text { Aglais urticae } \\
\text { (Nymphalidae) }\end{array}$ & $\mathrm{L}_{\mathrm{i}}$ & & $1(0.1)$ & & & & & & & \\
\hline $\begin{array}{l}\text { Vanessa atalanta } \\
\text { (Nymphalidae) }\end{array}$ & $\mathrm{L}_{\mathrm{i}}$ & $2(0.1)$ & $7(0.8)$ & & & & & & & \\
\hline $\begin{array}{l}\text { Vanessa cardui } \\
\text { (Nymphalidae) }\end{array}$ & $\mathrm{L}_{\mathrm{i}}$ & & $\begin{array}{l}38 \\
(4.6)\end{array}$ & & & & & & & \\
\hline Total no. of visits & & 2181 & 830 & 467 & 2126 & 966 & 5602 & 4162 & 897 & 4593 \\
\hline
\end{tabular}

Values are given as total number of flower visited followed by the percentage of floral interactions in parenthesis. The floral visitors were characterized according with the type of visit as $L$ legitimate visitor, $L_{i}$ legitimate ineffective visitor, $R$ nectar robber, $S R$ secondary nectar robber, $T$ nectar thief (Inouye 1980). Empty cells represent zero visits by a given insect to the flowers of $P$. vayredae

\section{References}

Aizen MA, Harder LD (2007) Expanding the limits of the pollen-limitation concept: effects of pollen quantity and quality. Ecology 88:271-281

Anderso MJ (2001) A new method for non-parametric multivariate analysis of variance. Austral Ecol 26:32-46

Arizmendi M, Domínguez C, Dirzo R (1996) The role of an avian nectar robber and of hummingbird pollinators in the reproduction of two plant species. Funct Ecol 10:119-127

Artz DR, Villagra CA, Raguso RA (2010) Spatiotemporal variation in the reproductive ecology of two parapatric subspecies of Oenothera cespitosa (Onagraceae). Am J Bot 97:1498-1510

Ashman TL, Knight TM, Steets JA, Amarasekare P, Burd M, Campbell DR, Dudash MR, Johnston MO, Mazer SJ, Mitchell RJ, Morgan MT, Wilson WG (2004) Pollen limitation of plant reproduction: ecological and evolutionary causes and consequences. Ecology 85:2408-2421
Caruso CM, Peterson SB, Ridley CE (2003) Natural selection on floral traits of Lobelia (Lobeliaceae): spatial and temporal variation. Am J Bot 90:1333-1340

Castro S, Silveira P, Navarro L (2008a) How flower biology and breeding system affect the reproductive success of the narrow endemic Polygala vayredae Costa (Polygalaceae). Bot J Linn Soc 157:67-81

Castro S, Silveira P, Navarro L (2008b) How does secondary pollen presentation affect the fitness of Polygala vayredae (Polygalaceae)? Am J Bot 95:706-712

Castro S, Silveira P, Navarro L (2008c) Consequences of nectar robbing in the fitness of a threatened plant species. Plant Ecol 199:201-208

Castro S, Silveira P, Navarro L, Paiva J, Coutinho AP (2009a) Pollen morphology of Chamaebuxus (DC.) Schb., Chodatia Paiva and Rhinotropis (Blake) Paiva (Polygala L., Polygalaceae). Grana 48:179-192

Castro S, Silveira P, Navarro L (2009b) Floral traits variation, legitimate pollination, and nectar robbing in Polygala vayredae (Polygalaceae). Ecol Res 24:47-55 
Castro S, Silva S, Stanescu I, Silveira P, Navarro L, Santos C (2009c) Pistil anatomy and pollen tube development in Polygala vayredae Costa (Polygalaceae). Plant Biol 11: 405-416

Dafni A, Kevan P, Husband BC (2005) Practical pollination biology. Enviroquest, Ltr, Cambridge

Fenster CB, Dudash MR (2001) Spatiotemporal variation in the role of hummingbirds as pollinators of Silene virginica. Ecology 82:844-851

Ferrero V, Castro S, Sánchez JM, Navarro L (2011) Stigmaanther reciprocity, pollinators and pollen transfer efficiency in populations of heterostylous species of Lithodora and Glandora (Boraginaceae). Plant Syst Evol 291: 267-276

Ghazoul J (2006) Floral diversity and the facilitation of pollination. J Ecol 94:295-304

Gómez JM, Zamora R (1999) Generalization vs. specialization in the pollination system of Hormathophylla spinosa (Cruciferae). Ecology 80:796-805

Goulson D (2000) Foraging strategies of insects for gathering nectar and pollen, and implications for plant ecology and evolution. Perspect Plant Ecol Evol Syst 2:185-209

Guitián J, Guitián P, Navarro L (1996) Spatio-temporal variation in the interactions between Cornus sanguinea and its pollinators. Acta Oecol 17:285-295

Hammer $\varnothing$, Harper DAT, Ryan PD (2001) PAST: paleontological statistics software package for education and data analysis. Palaeontol Electronica 4:9

Hargreaves AL, Harder LD, Johnson SD (2009) Consumptive emasculation: the ecological and evolutionary consequences of pollen theft. Biol Rev 84:259-276

Herrera CM (1988) Variation in mutualisms: the spatiotemporal mosaic of a pollinator assemblage. Biol J Linn Soc 35: 95-125

Herrera CM (1989) Pollinator abundance, morphology, and flower visitation rate: analysis of the "quantity" component in a plant-pollinator system. Oecologia 80:241-248

Herrera CM (1993) Selection on floral morphology and environmental determinants of fecundity in a hawk moth-pollinated violet. Ecol Monogr 63:251-275

Herrera CM, Medrano M, Rey PJ, Sánchez-Lafuente AM, Garcíam MB, Guitián J (2002) Interaction of pollinators and herbivores on plant fitness suggests a pathway for correlated evolution of mutualism- and antagonism-related traits. Proc Natl Acad Sci 99:16823-16828

Inouye DW (1980) The terminology of floral larceny. Ecology 61:1251-1253

Irwin RE, Brody AK (1999) Nectar-robbing bumble bees reduce the fitness of Ipomopsis aggregata (Polemoniaceae). Ecology 80:1703-1712

Irwin RE, Brody A, Waser NM (2001) The impact of floral larceny on individuals, populations, and communities. Oecologia 129:161-168

Jersáková J, Johnson SD, Kindlmann P (2006) Mechanisms and evolution of deceptive pollination in orchids. Biol Rev 81:219-235
Knight TM, Steets JA, Vamosi JC, Mazer SJ, Burd M, Campbell DR, Dudash MR, Johnston MO, Mitchell RJ, Ashman TL (2005) Pollen limitation of plant reproduction: pattern and process. Annu Rev Ecol Evol Syst 36:467-497

Moeller DA (2006) Geographic structure of pollinator communities, reproductive assurance, and the evolution of selfpollination. Ecology 87:1510-1522

Navarro L (1998) Effect of pollen limitation, additional nutrients, flower position and flowering phenology on fruit and seed production in Salvia verbenaca (Lamiaceae). Nord J Bot 18:441-446

Navarro L (2000) Pollination ecology of Anthyllis vulneraria subsp. vulgaris (Fabaceae): nectar robbers as pollinators. Am J Bot 87:980-985

Navarro L (2001) Reproductive biology and effect of nectar robbing on fruit production on Macleania bullata (Ericaceae). Plant Ecol 152:59-65

Navarro L, Medel R (2009) Relationship between floral tube length and nectar robbing in Duranta erecta L. (Verbenaceae). Biol J Linn Soc 96:392-398

Navarro L, Guitián J, Guitián P (1993) Reproductive biology of Petrocoptis grandiflora Rothm. (Caryophyllaceae), a species endemic to the Northwest Iberian Peninsula. Flora 188:253-261

Navarro L, Guitián P, Ayensa G (2008) Pollination ecology of Disterigma stereophyllum (Ericaceae) in Southwestern Colombia. Plant Biol 10:512-518

Pellmyr O, Thompson JN (1996) Sources of variation in pollinator contribution within a build: the effects of plant and pollinator factors. Oecologia 107:595-604

Sahly HF, Conner JK (2007) Visitation, effectiveness, and efficiency of 15 genera of visitors to wild radish, Raphanus raphanistrum (Brassicaceae). Am J Bot 94:203-209

Schemske DW, Horvitz CC (1984) Variation among floral visitors in pollination ability: a precondition for mutualism specialization. Science 225:519-521

Schemske DW, Husband BC, Ruckelshaus MH, Goodwillie C, Parker IM, Bishop JG (1994) Evaluating approaches to the conservation of rare and endangered plants. Ecology 75:584-606

Traveset A, Sáez E (1997) Pollination of Euphorbia dendroides by lizards and insects: spatio-temporal variation in patterns of flower visitation. Oecologia 111:241-248

Vicens N, Bosch J (2000) Weather-dependent pollinator activity in an apple orchard, with special reference to Osmia cornuta and Apis mellifera (Hymenoptera: Megachilidae and Apidae). Environ Entomol 29:413-420

Waser NM, Chittka L, Price MV, Williams NM, Ollerton J (1996) Generalization in pollination systems, and why it matters. Ecology 77:1043-1070

Zhang Y-W, Robert G, Wang Y, Guo Y-H (2007) Nectar robbing of a carpenter bee and its effects on the reproductive fitness of Glechoma longituba (Lamiaceae). Plant Ecol 193:1-13 